\title{
Recent Black-throated Blue Warbler Records in Saskatchewan
}

\section{by Douglas E. Wade, Regina}

Black-throated Blue Warblers have been seen in Saskatchewan on three different dates and in three locations during 1963. Two adult males were seen and heard at Cypress Hills Provincial Park near the park headquarters' office on IMay 29 by the writer. The next day the writer saw two adult males in heavy aspen woodland along Lone Pine Creek about one and a half miles south of the park headquarters' office. There is some possibility that the birds seen on May 30 were the same as those of May 29. The writer is familiar with this warbler, having seen and heard it annually and quite frequently in eastern North America over a period of 16 years. Godfrey (1950) in Birds of the Cypress Hills ans. Flotten Lake Regions, Saskatchewan, does not list this warbler. The bird has been added to the list of birds of Cypress Hills Provincial Park published by the Department of Natural Resources.

On June 1, 1963, Mr. and Mrs. Herbert Tempel saw and heard an adult male Black-throated Blue Warbler in their backyard at 45 Langley Crescent, Regina. Called to Langley Crescent by the Tempels, the writer and his wife and Dr. and Mrs. Robert Nero saw and heard the warbler. It is interesting to note that a dead male Black-throated Blue Warbler was found by Chris Davis on October 20,1960 , at a location about one block from the Tempel's home (Belcher, Birds of Regina). Belcher also lists one other record for Regina, a male seen in late May, 1935.

On the afternoon of October 18, 1963, Mrs. Betty Cruickshank of Regina had a male Black-throated Blue Warbler under observation for over an hour and within a few feet of her glass-enclosed front porch. This male was in excellent plumage and was apparently feeding while moving rapidly about in bushes. Mrs. Cruickshank made an effort to get in touch with other birders at the time, but apparently many had already departed for Moose Jaw to attend the SNHS annual meeting.

The three records for 1963 of the Black-throated Blue Warbler in
Saskatchewan are of interest because this warbler, though common in the eastern deciduous woodlands, is rarely reported in the prairie provinces. In $1954 \mathrm{R}$. W. Nero summarized the then-known records for the province as follows (Blue Jay, 14:3): "The first [specimen], an adult male, was collected at Percival, Saskatchewan, on October 21, 1936, by John and Robert Nelson . . . Mowat [ 1947. Notes on the birds of Emma Lake, Saskatchewan. Can. Field-Nat., 61: 105-115] reported some sight observations of this species in June and July, 1939, at Emma Lake, and Potter [1943. Bird notes from southwestern Saskatchewan. Can. FieldNat., 57:69-72] observed a male at Eastend on September 21, 1947." The occasion for Dr. Nero's review of these records was the recovery of a specimen at Moose Jaw on October 16, 1955, by John A. Livingston and George Ledingham-an immature female that flew against a window pane. The third specimen for the province, the one picked up by Chris Davis on October 20, 1960, was also reported in the Blue Jay (18:156) by Dr. Nero.

\section{NEST RECORD CARDS}

If you have nest records for 1963 which have not been submitted to the Prairie Nest Records Scheme, we should be glad to have them from you as soon as possible so that all information can be summarized for a report in the Blue Jay. We apologize for the long delay this summer in sending cards to our regular contributors. The former chairman had to give up the scheme last spring and mail that came to the scheme was not attended to until this fall. At the Annual Meeting, October 19, 1963, Robert Taylor, of Regina, was appointed as the new chairman.

Send all cards and inquiries for cards to:

Robert Taylor,

Prairie Nest Records Scheme,

Blue Jay, Box 1121, Regina. 